Article

\title{
Assessment of an MnCe-GAC Treatment Process for Tetramethylammonium-Contaminated Wastewater from Optoelectronic Industries
}

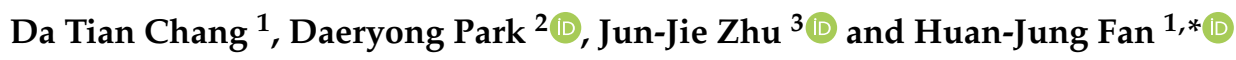 \\ 1 Department of Environmental, Safety and Health Engineering, Hungkuang University, Taichung 43302, \\ Taiwan; chang.da.tina@gmail.com \\ 2 Department of Civil and Environmental Engineering, Konkuk University, 120 Neungdong-ro, Gwangjin-gu, \\ Seoul 05029, Korea; drpark@konkuk.ac.kr \\ 3 Department of Civil, Architectural and Environmental Engineering, Illinois Institute of Technology, Chicago, \\ IL 60616-3793, USA; jzhu21@iit.edu \\ * Correspondence: fan@hk.edu.tw
}

Received: 11 September 2019; Accepted: 23 October 2019; Published: 28 October 2019

check for updates

Featured Application: The process proposed in this study could be an effective method for the treatment of high-tech industrial wastewater to meet the new tetramethylammonium hydroxide (TMAH) discharge limit.

\begin{abstract}
Nitrogen-containing wastewater is an important issue in optoelectronic and semiconductor industries. Wastewater containing nitrogen compounds such as ammonium, monoethanolamine (MEA), and tetramethylammonium hydroxide (TMAH) must be properly treated due to concerns about health and environmental effects. MnCe-GAC (granular activated carbon) processes were developed in this study for the treatment of TMAH-contaminated wastewater in high-tech industries. The MnCe-GAC processes could effectively remove ammonium, MEA, and TMAH from aqueous solutions. The removal efficiencies of ammonium and MEA by these processes were better than observed for TMAH. Parameters affecting TMAH removal such as type of process, type of wastewater (synthetic or real), $\mathrm{pH}$, salts, and t-butanol were investigated. In general, removal efficiencies of TMAH by various processes were in the following order: $\mathrm{MnCe}-\mathrm{GAC} / \mathrm{O}_{3} / \mathrm{H}_{2} \mathrm{O}_{2}>\mathrm{MnCe}-\mathrm{GAC} / \mathrm{O}_{3}$ $>$ MnCe-GAC $/ \mathrm{H}_{2} \mathrm{O}_{2}>$ MnCe-GAC $>$ GAC. The negative effect of sulfate and nitrate on pollutant removal might be due to the salting-out effect. Based on t-butanol experiments, the main degradation mechanisms of TMAH by the MnCe- $G A C / \mathrm{O}_{3} / \mathrm{H}_{2} \mathrm{O}_{2}$ process likely involved hydroxyl radicals. The process proposed in this study could be an effective alternative method for the treatment of high-tech industrial wastewater to meet the new TMAH discharge limit.
\end{abstract}

Keywords: TMAH; MEA; MnCe-GAC; high-tech; wastewater

\section{Introduction}

Nitrogen-containing wastewater is an important issue in high-tech industries such as optoelectronic and semiconductor manufacturing industries. For example, in thin-film transistor liquid crystal display (TFT-LCD) manufacturing processes, wastewater containing high concentrations of nitrogen compounds (such as ammonium $\left(\mathrm{NH}_{4}{ }^{+}\right.$), monoethanolamine (MEA), or tetramethylammonium hydroxide (TMAH)) is generated [1,2]. TMAH is a caustic developing fluid, widely used in the manufacture of TFT-LCD and light emitting diodes (TFT-LED) and in semiconductor industries as a developer or etchant [2-4]. For example, a TFT-LCD factory (sixth generation) could generate 30,000 cubic meter per day (CMD) of TMAH-containing wastewater [5]. In Japan, one factory could 
discharge roughly 2500 tons of TMAH per year [6]. In addition, MEA is used as a stripper in the manufacture of TFT-LCD [7]. Exposure to TMAH may result in muscle weakness, muscular paralysis, dyspnea, hyperglycemia, respiratory deterioration, alkaline chemical burns, and/or sudden death [8-10]. For example, Lin et al. [10] reported on three fatal incidents in Taiwan due to TMAH exposure. TMAH must be properly treated before discharge due to its health and environmental effects [11]. These pollutants in wastewater discharged from TFT-LCD manufacturing factories are already being legislatively regulated in Taiwan and Japan [9]. In addition, the TMAH effluent standard at the Hsinchu Industrial Science Park, Taiwan, was modified from 60 to $30 \mathrm{mg} / \mathrm{L}$ in 2015 due to human health and environmental concerns. High concentrations of TMAH solutions from factories could be physicochemically recovered and recycled, while wastewater containing lower concentrations of TMAH (in the order of hundreds of $\mathrm{mg} / \mathrm{L}$ ) can be treated in wastewater treatment facilities $[9,12]$.

Common treatment processes for nitrogen-containing wastewater include adsorption [13-15], biological processes [9,11], ozonation [16], chemical oxidation [17], electrodialysis [18], and UV/persulfate $[19,20]$. Although wastewater containing high concentrations of TMAH can be treated by Fenton oxidation and catalytic oxidation processes, costs of these processes can be very high [11]. The TFT-LCD industry contributed more than 100 billion dollars annually due to the growing demand in electronic products [2]. There is a need to develop effective processes for the removal of nitrogen-containing wastewater because meeting the new TMAH effluent standard will not be an easy task. An alternative effective treatment process (MnCe- $\mathrm{GAC} / \mathrm{O}_{3} / \mathrm{H}_{2} \mathrm{O}_{2}$ ) for the treatment of nitrogen-containing wastewater is proposed and investigated in this study.

\section{Materials and Methods}

Samples of wastewaters discharged from four optoelectronic (Plants 1-4) and six semiconductor (Plants 5-10) plants in Central Taiwan Science Park, Taiwan, were collected and analyzed in this research, and their temperature, conductivity, suspended solids (SS), chemical oxygen demand (COD), biological oxygen demand (BOD), nitrate, sulfate, ammonium, and TMAH are summarized in Table 1. Plant 1 is a LCD glass substrate (LCD-GS) manufacturing factory, Plant 2 is a photovoltaic cell (PV) and TFT-LCD manufacturing factory, Plants 3-4 are TFT-LCD manufacturing factories, Plant 5 is an integrated circuit (IC) design and manufacturing factory (including flash memory (FM) and dynamic random access memory (DRAM), Plants 6-9 are IC manufacturing factories, and Plant 10 is an IC packaging and testing factory (IC-P\&T). Plant 3 is a typical TF-LCD manufacturing plant with a relatively high wastewater flow rate (12,381 CMD) and pollutant concentrations (SS 79.4 mg/L, COD $296.6 \mathrm{mg} / \mathrm{L}, \mathrm{BOD} 169.43 \mathrm{mg} / \mathrm{L}, \mathrm{NH}_{3}-\mathrm{N} 9.78 \mathrm{mg} / \mathrm{L}, \mathrm{TMAH} 100.21 \mathrm{mg} / \mathrm{L}$ ) among these plants. It was chosen for the subsequent real wastewater test. The experimental set-up of MnCe-GAC (granular activated carbon) processes (Figure 1) made it possible to explore ten treatment processes: GAC, MnCe-GAC, $\mathrm{O}_{3}, \mathrm{GAC} / \mathrm{O}_{3}, \mathrm{MnCe}-\mathrm{GAC} / \mathrm{O}_{3}, \mathrm{H}_{2} \mathrm{O}_{2}, \mathrm{GAC} / \mathrm{H}_{2} \mathrm{O}_{2}, \mathrm{MnCe}-\mathrm{GAC} / \mathrm{H}_{2} \mathrm{O}_{2}, \mathrm{GAC} / \mathrm{O}_{3} / \mathrm{H}_{2} \mathrm{O}_{2}$, and MnCe-GAC/O $\mathrm{O}_{3} / \mathrm{H}_{2} \mathrm{O}_{2}$. Since salts might be present in wastewaters, the effect of three model salts (including sulfate, nitrate, and carbonate) on the processes was investigated. Both synthetic (ammonium, MEA, or TMAH) and real wastewater (Plant 3) samples were treated by the above processes. A known amount of solid (1.0 g of GAC or MnCe-GAC) was packed in a column (internal diameter $1.1 \mathrm{~cm}$, column height $3.9 \mathrm{~cm}$, flow rate $100 \mathrm{~mL} / \mathrm{min})$. A vessel $(500 \mathrm{~mL})$ was filled with known concentrations of a target solution (ammonium, MEA, or TMAH) with $\mathrm{pH}$ adjusted to the desired values $(3,7$, or 11$)$, and the solution was circulated through the column as indicated in Figure 1. A known amount of $\mathrm{O}_{3}$ and/or $\mathrm{H}_{2} \mathrm{O}_{2}$ was added into the system as the process required. Samples were collected, filtered, and analyzed in triplicate within acceptable analytical error $( \pm 5 \%)$. TMAH, monomethylamine $\left(\mathrm{MH}, \mathrm{CH}_{6} \mathrm{ClN}\right)$, dimethylamine $\left(\mathrm{DH}, \mathrm{C}_{2} \mathrm{H}_{8} \mathrm{ClN}\right)$, and trimethylamine $(\mathrm{TH}$, $\mathrm{C}_{3} \mathrm{H}_{10} \mathrm{ClN}$ ) concentrations were analyzed by Dionex ICS-1100 ion chromatography system with Ion Pac CS19A IC columns and Dionex CERSTM 300. 
Table 1. Characteristics of wastewaters discharged from high-tech industry plants $(n=3)$.

\begin{tabular}{|c|c|c|c|c|c|c|c|c|c|c|c|}
\hline Plant ${ }^{(1)}$ & Product & $\mathrm{pH}$ & Cond. (2) & SS & COD & BOD & Nitrate & Sulfate & $\mathrm{NH}_{3}-\mathrm{N}$ & ТМАН & Discharge \\
\hline & & & $\mu \mathrm{S} / \mathrm{cm}$ & $\mathrm{mg} / \mathrm{L}$ & $\mathrm{mg} / \mathrm{L}$ & $\mathrm{mg} / \mathrm{L}$ & $\mathrm{mg} / \mathrm{L}$ & $\mathrm{mg} / \mathrm{L}$ & $\mathrm{mg} / \mathrm{L}$ & $\mathrm{mg} / \mathrm{L}$ & CMD \\
\hline Plant 1 & LCD-GS & 7.1 & 1351 & 32.7 & 82.2 & 38.44 & 6.84 & 130.46 & 2.12 & 35.03 & 5447 \\
\hline Plant 3 & TFT-LCD & 6.9 & 3588 & 79.4 & 296.6 & 169.43 & 42.18 & 160.32 & 9.78 & 100.21 & 12,381 \\
\hline Plant 4 & TFT-LCD & 6.7 & 3254 & 82.0 & 205.1 & 70.31 & 15.25 & 309.75 & 1.73 & 64.97 & 8738 \\
\hline Plant 5 & FM, DRAM & 6.9 & 1546 & 16.1 & 28.8 & 14.78 & 8.01 & 281.31 & 6.87 & 39.76 & 5691 \\
\hline Plant 8 & IC & 6.4 & 10,941 & 6.5 & 137.3 & 37.87 & 96.99 & 3167.68 & 13.96 & 109.43 & 4062 \\
\hline Plant 9 & IC & 6.5 & 10,643 & 25.0 & 335.7 & 139.33 & 166.73 & 1212.35 & $\mathrm{ND}^{(3)}$ & 84.38 & 17,778 \\
\hline Plant 10 & IC-P\&T & 7.2 & 1568 & 33.3 & 40.3 & 13.65 & 78.31 & 337.31 & ND & 27.33 & 3586 \\
\hline
\end{tabular}

(1) LCD-GS = LCD glass substrate; PV = photovoltaic cells; FM = flash memory; IC-P\&T = IC packaging and testing;

(2) Cond. = conductivity; ${ }^{(3)} \mathrm{ND}=$ under detection limit.

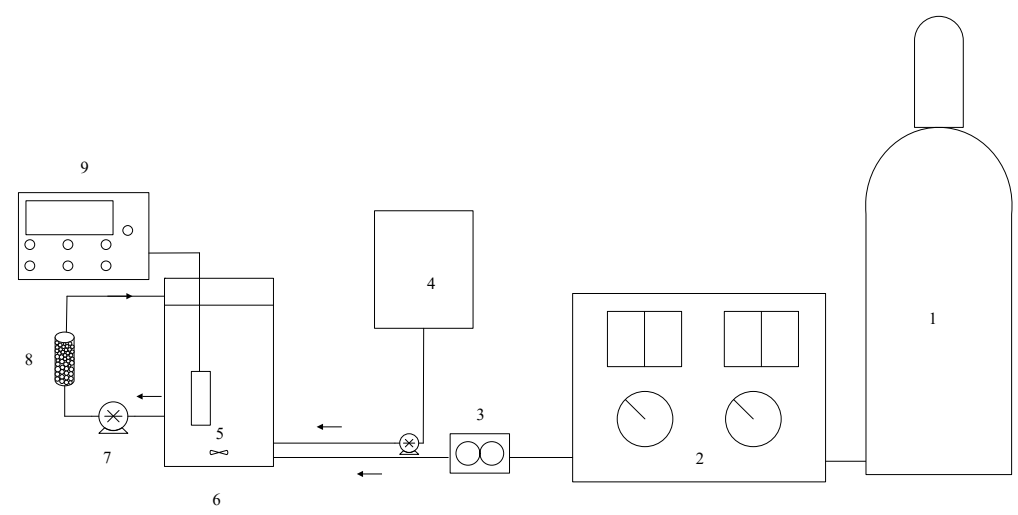

Figure 1. Experimental set-up of MnCe-GAC processes (1-oxygen cylinder, 2-ozone generator, 3-flow meter, 4-hydrogen peroxide storage tank, 5-mixer, 6-reactor, 7-peristaltic pump, 8 -activated carbon, 9- $\mathrm{pH}$ meter).

MnCe-GAC was prepared by impregnating Mn and Ce oxides onto GAC (F400, Calgon Carbon Corporation) surfaces. For example, known amounts of $\mathrm{Mn}\left(\mathrm{NO}_{3}\right)_{2} \cdot 4 \mathrm{H}_{2} \mathrm{O}$ and $\mathrm{Ce}\left(\mathrm{NO}_{3}\right)_{3} \cdot 6 \mathrm{H}_{2} \mathrm{O}$ solids (molar ratio of $\mathrm{Mn}: \mathrm{Ce}=6: 4$ ) were dissolved in deionized water. A known amount of GAC was immersed in the above solution and sonicated for $30 \mathrm{~min}$ before being dried in an oven at $90^{\circ} \mathrm{C}$ for $12 \mathrm{~h}$. The resulting mixture was heated at $200{ }^{\circ} \mathrm{C}$ for $120 \mathrm{~min}$ and then washed several times with deionized water to remove detachable $\mathrm{Mn}$ and Ce oxides. The resulting composite (MnCe-GAC) was dried at $105^{\circ} \mathrm{C}$ and stored at room temperature until needed. Apparent bulk density, particle density, and pore volume fraction of GAC were $0.54 \mathrm{~kg} / \mathrm{L}, 0.78 \mathrm{~kg} / \mathrm{L}$, and $0.82 \mathrm{~kg} / \mathrm{L}$, respectively. Prior to being used in this study, GAC was sieved so that the particle size was between 0.425 and $0.600 \mathrm{~mm}$, washed several times with deionized water, and baked in an oven at $200^{\circ} \mathrm{C}$. The BET-pecific surface areas and surface morphology of MnCe-GAC and GAC were examined by ASAP 2010 accelerated surface area and porosimetry system (Micromeritics, Norcross, GA, USA) and field emission scanning electron microscope (FE-SEM) (SEM, ABT-150S, Topcon, Japan), respectively.

The amount of $\mathrm{Mn}$ and Ce impregnated on MnCe-GAC was measured by extracting MnCe-GAC in a $\mathrm{HNO}_{3}(10 \%)$ solution for $3 \mathrm{~h}$ at $180{ }^{\circ} \mathrm{C}$. Total $\mathrm{Mn}$ or $\mathrm{Ce}$ in the extracted solution was measured by inductively coupled plasma (ICP-AES, Kontron, S-35). The amount of Mn and Ce on the spent MnCe-GAC (after treatment) was measured as well. The loss of Mn and Ce on MnCe-GAC after the treatment processes was determined by comparing the amount of $\mathrm{Mn}$ and Ce between newly prepared MnCe-GAC and spent MnCe-GAC. All labware were acid washed and thoroughly rinsed with deionized water. Chemicals used in this study were reagent grade, unless specified. Hydrogen peroxide (35\%) was purchased from Sigma-Aldrich Chemical Co. $\mathrm{H}_{2} \mathrm{O}_{2}$ was added into the reactor by a syringe pump at a constant feed rate. Ozone was produced by the ozone generator OW-K2/O 
(Taiwan) and was introduced into the reactor via a fine bubble diffusor. A standard iodometric titration method was used to determine the concentration of ozone [21].

\section{Results and Discussion}

\subsection{Characteristics of Wastewater Composition from Photoelectric and Semiconductor Factories}

Wastewaters from four photoelectric (Plants1-4) and six semiconductor (Plants 5-10) plants were shown in Table 1. Most of these plants (except Plant 10) had higher TMAH concentrations than the discharge limit (30 mg/L).

\subsection{Characteristics of $M n C e-G A C$}

The BET-specific surface areas for GAC and MnCe-GAC were approximately 811 and $590 \mathrm{~m}^{2} / \mathrm{g}$, respectively. The lower surface area of MnCe-GAC indicated that some of the pores of GAC might be blocked by the impregnation of Mn and Ce on the GAC surface. Surface characteristics of GAC and MnCe-GAC were further examined by SEM as shown in Figure $2 a$ and $b$, respectively. The amount of Mn and Ce on MnCe-GAC surfaces was approximately $65.1 \mathrm{mg} \mathrm{Mn} / \mathrm{g}$ (SD = $1.5 \mathrm{mg} \mathrm{Mn} / \mathrm{g}$ ) and $27.0 \mathrm{mg} \mathrm{Ce} / \mathrm{g}$ (SD = $1.1 \mathrm{mg} \mathrm{Ce} / \mathrm{g}$ ), respectively. The loss of Mn and Ce on MnCe-GAC was determined by comparing the amount of $\mathrm{Mn}$ and Ce on MnCe-GAC before and after the treatment processes. In these tests, the total loss of Mn and Ce was less than $6 \%$. This result indicated that MnCe-GAC has the potential to be reused.

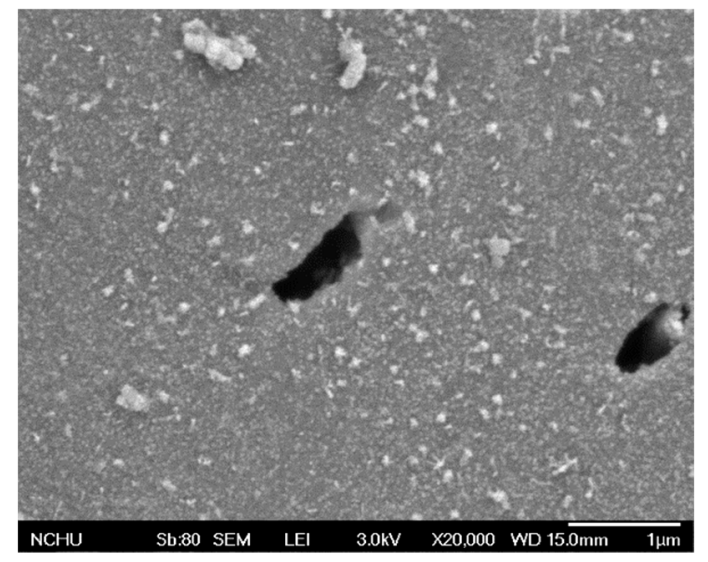

(a)

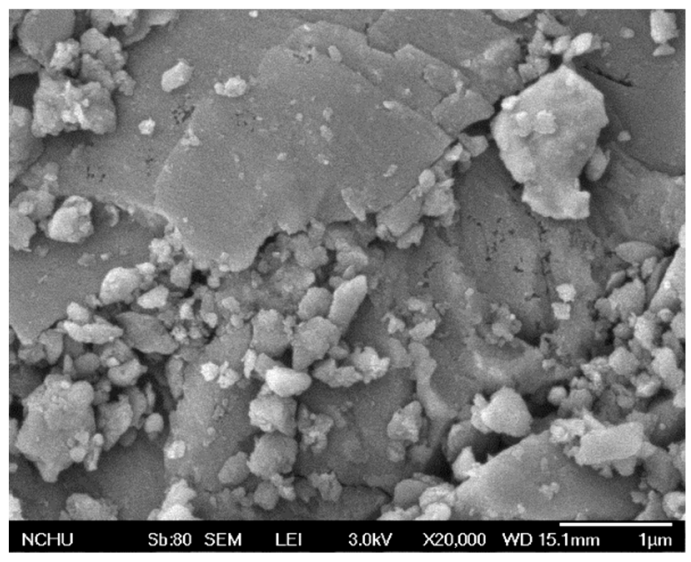

(b)

Figure 2. SEM images of (a) GAC and (b) MnCe-GAC.

\subsection{Removal of Ammonium, MEA, and TMAH by Various Processes (Synthetic Wastewater)}

Removal results for ammonium, MEA, and TMAH by the processes examined in this study (GAC, MnCe-GAC, $\mathrm{O}_{3}, \mathrm{H}_{2} \mathrm{O}_{2}, \mathrm{GAC} / \mathrm{O}_{3}, \mathrm{GAC} / \mathrm{H}_{2} \mathrm{O}_{2}$, MnCe-GAC/O ${ }_{3}, \mathrm{MnCe}-\mathrm{GAC} / \mathrm{H}_{2} \mathrm{O}_{2}, \mathrm{GAC} / \mathrm{O}_{3} / \mathrm{H}_{2} \mathrm{O}_{2}$, and MnCe-GAC/O $\left.\mathrm{O}_{3} / \mathrm{H}_{2} \mathrm{O}_{2}\right)$ are shown in Figure $3\left(\mathrm{pH} 11, \mathrm{C}_{\mathrm{o}}=100 \mathrm{mg} / \mathrm{L}, \mathrm{V}=0.5 \mathrm{~L}\right.$, solid $1 \mathrm{~g}, 0.25 \mathrm{mmol}$ $\mathrm{O}_{3} / \mathrm{min}, 0.125 \mathrm{mmol} \mathrm{H}_{2} \mathrm{O}_{2} / \mathrm{min}, 30 \mathrm{~min}$ ). In general, the removal efficiencies of ammonium and MEA by these processes were better than that of TMAH. For example, the removal efficiencies of ammonium, MEA, and TMAH by MnCe-GAC/O $/ \mathrm{H}_{2} \mathrm{O}_{2}$ were $92.3,71.6$, and $42.0 \%$, respectively. This result is in agreement with Lei et al. [11]. They reported that the degradation rate of MEA was significantly higher than that of TMAH. In addition, the ozone processes $\left(\mathrm{O}_{3}, \mathrm{GAC} / \mathrm{O}_{3}\right.$, and MnCe-GAC/O $\left.\mathrm{O}_{3}\right)$ had slightly better removal efficiencies (40,50, and $64 \%$ for ammonium removal, respectively) than the $\mathrm{H}_{2} \mathrm{O}_{2}$ processes $\left(\mathrm{H}_{2} \mathrm{O}_{2}, \mathrm{GAC} / \mathrm{H}_{2} \mathrm{O}_{2}\right.$, and MnCe-GAC/ $\mathrm{H}_{2} \mathrm{O}_{2} ; 28,38$, and $61 \%$ ammonium removal, respectively) (Figure 3). The removal of ammonium and MEA by the MnCe- $\mathrm{GAC} / \mathrm{O}_{3} / \mathrm{H}_{2} \mathrm{O}_{2}$ process was slightly better than that observed for the $\mathrm{GAC} / \mathrm{O}_{3} / \mathrm{H}_{2} \mathrm{O}_{2}$ process. However, the removal of TMAH by the MnCe-GAC/O $\mathrm{O}_{3} / \mathrm{H}_{2} \mathrm{O}_{2}$ process (42\%) was significantly greater than that observed for 
the GAC/O $\mathrm{O}_{3} / \mathrm{H}_{2} \mathrm{O}_{2}$ process (29\%) (Figure 3). The addition of $\mathrm{H}_{2} \mathrm{O}_{2}$ could improve the removal of pollutants in wastewater in ozonation processes and it might be due to the formation of $\bullet \mathrm{OH}$ radicals by the conjugated base of $\mathrm{H}_{2} \mathrm{O}_{2}$ with ozone [16,22-25]. In addition, an overdose of $\mathrm{H}_{2} \mathrm{O}_{2}$ might act as a scavenger and react with $\bullet \mathrm{OH}$ instead of ozone. Therefore, the overall removal efficiency might be hindered by the overdose of $\mathrm{H}_{2} \mathrm{O}_{2}$. Therefore, the ratio of $\mathrm{H}_{2} \mathrm{O}_{2} / \mathrm{O}_{3}$ applied in the process is important. The stoichiometric molar ratio of $\mathrm{H}_{2} \mathrm{O}_{2} / \mathrm{O}_{3}$ being 1/2 [16] was applied in the study to ensure high efficiency of the treatment processes. As shown in Figure 3, MnCe- $G A C / \mathrm{O}_{3} / \mathrm{H}_{2} \mathrm{O}_{2}$ had the highest removal efficiencies among these processes for ammonium, MEA, and TMAH removal. This result indicated that the removal mechanism of the process is a combination of adsorption and degradation via catalysis/oxidation. The addition of $\mathrm{H}_{2} \mathrm{O}_{2}$ could improve the removal of pollutants in wastewater in ozonation processes. Therefore, this process was used in the subsequent experiments.

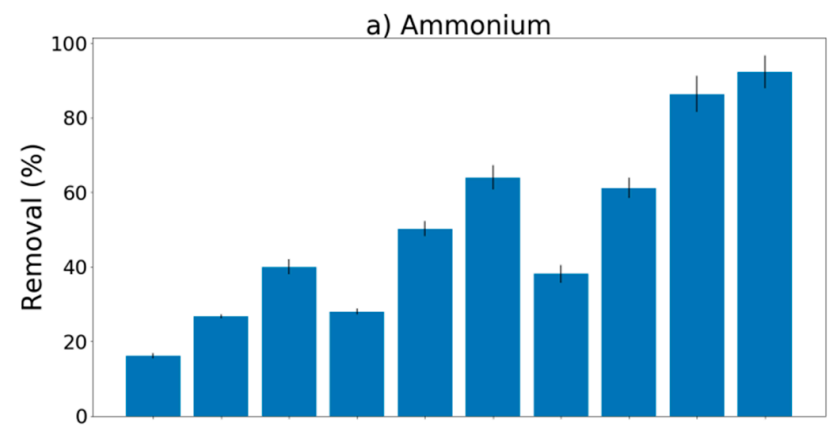

b) MEA

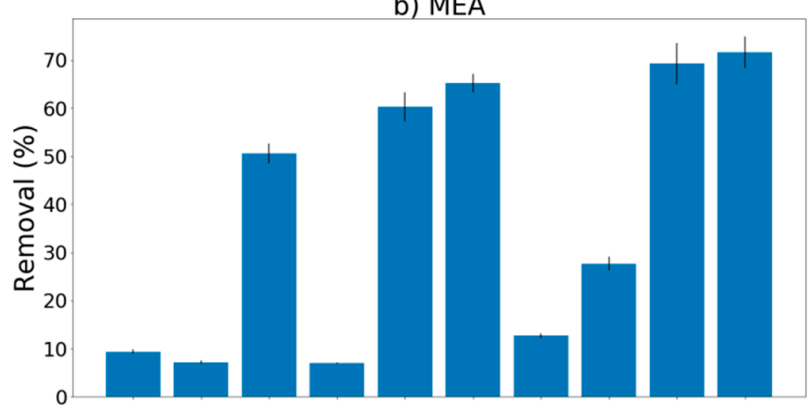

c) TMAH

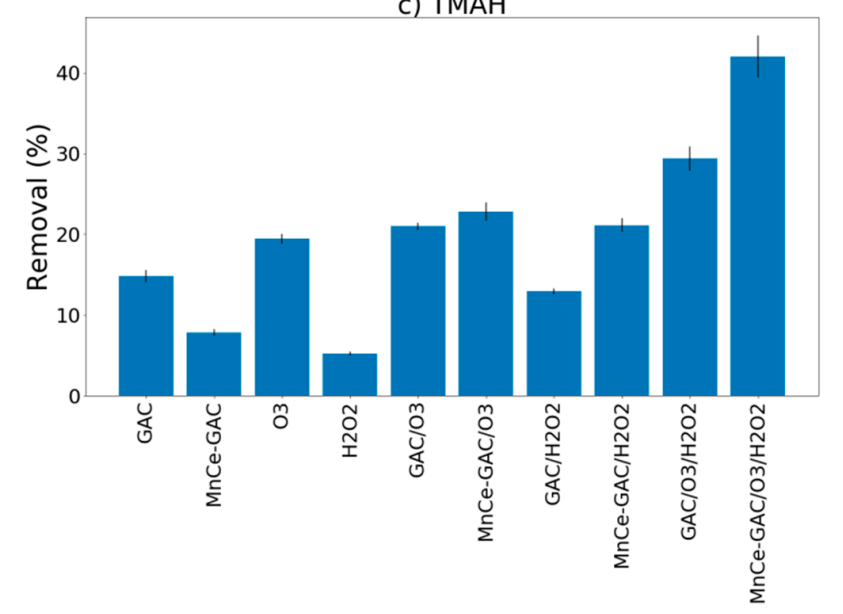

Figure 3. Removal of (a) Ammonium, (b) Monoethanolamine (MEA), and (c) Tetramethylammonium hydroxide (TMAH) by various processes $\left(\mathrm{pH} \mathrm{11}, \mathrm{C}_{\mathrm{o}}=100 \mathrm{mg} / \mathrm{L}, \mathrm{V}=0.5 \mathrm{~L}\right.$, solid $1 \mathrm{~g}, 0.25 \mathrm{mmol} \mathrm{O} / \mathrm{min}$, $0.125 \mathrm{mmol} \mathrm{H}_{2} \mathrm{O}_{2} / \mathrm{min}, 30 \mathrm{~min}$ ).

The solution $\mathrm{pH}$ played a significant role in these processes. A higher solution $\mathrm{pH}(\mathrm{pH} 11)$ had a better ammonium removal than those of $\mathrm{pH} 3$ and $\mathrm{pH} 7$ (Figure 4). For example, the removal of 
ammonium at $\mathrm{pH} 3,7$, and 11 by the $\mathrm{MnCe}-\mathrm{GAC} / \mathrm{O}_{3} / \mathrm{H}_{2} \mathrm{O}_{2}$ process were 34,61 , and $92 \%$, respectively $\left(\mathrm{C}_{\mathrm{o}}=100 \mathrm{mg} / \mathrm{L}, \mathrm{V}=0.5 \mathrm{~L}\right.$, solid $\left.1 \mathrm{~g}, 0.25 \mathrm{mmol} \mathrm{O}_{3} / \mathrm{min}, 0.125 \mathrm{mmol}_{2} \mathrm{O}_{2} / \mathrm{min}, 30 \mathrm{~min}\right)$. Similar results were obtained for the removal of TMAH by these processes (Figure 5). The solution $\mathrm{pH}$ had a significant impact on the removal of TMAH. In general, the order of removal efficiencies of TMAH is as follows: $\mathrm{pH} 11>\mathrm{pH} 7>\mathrm{pH}$ 3. At high $\mathrm{pH}$ values, ozone decomposes into nonselective hydroxyl radicals which oxidize organic pollutants. Similar $\mathrm{pH}$ effect was observed in the findings reported by Lu et al. [26] and the authors investigated using activated carbon/silver catalytic combined with ozone and hydrogen peroxide for the removal of TMAH. On the other hand, under acidic or neutral conditions, the direct attack on organic pollutants by molecular ozone occurs. In general, hydroxyl radicals could destroy organic compounds more effectively than ozone [16,27].
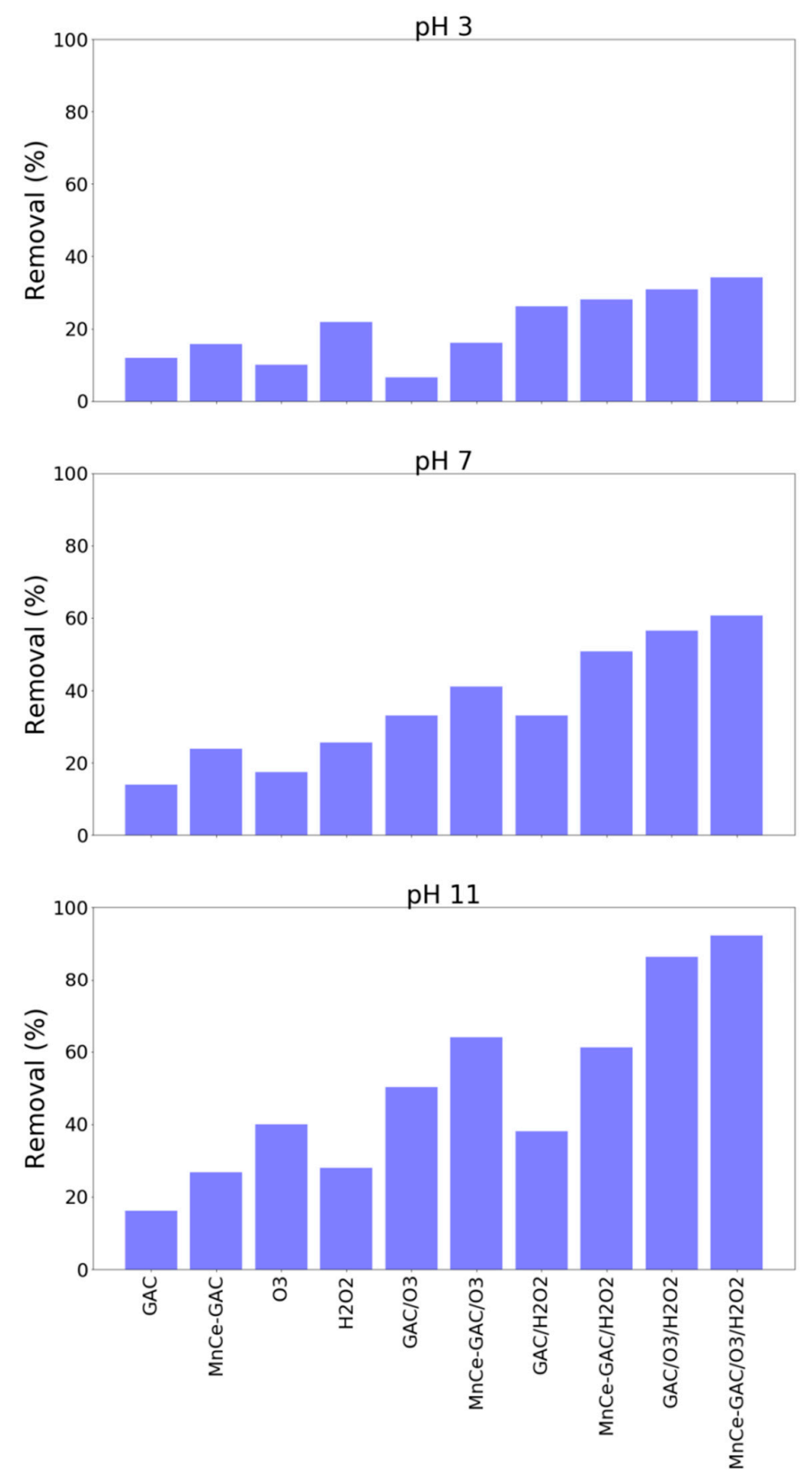

Figure 4. Removal of ammonium by various processes at various solution $\mathrm{pH}\left(\mathrm{C}_{\mathrm{o}}=100 \mathrm{mg} / \mathrm{L}, \mathrm{V}=0.5\right.$ $\mathrm{L}$, solid $1 \mathrm{~g}$, $0.25 \mathrm{mmol} \mathrm{O}_{3} / \mathrm{min}, 0.125 \mathrm{mmol} \mathrm{H}_{2} \mathrm{O}_{2} / \mathrm{min}, 30 \mathrm{~min}$ ). 

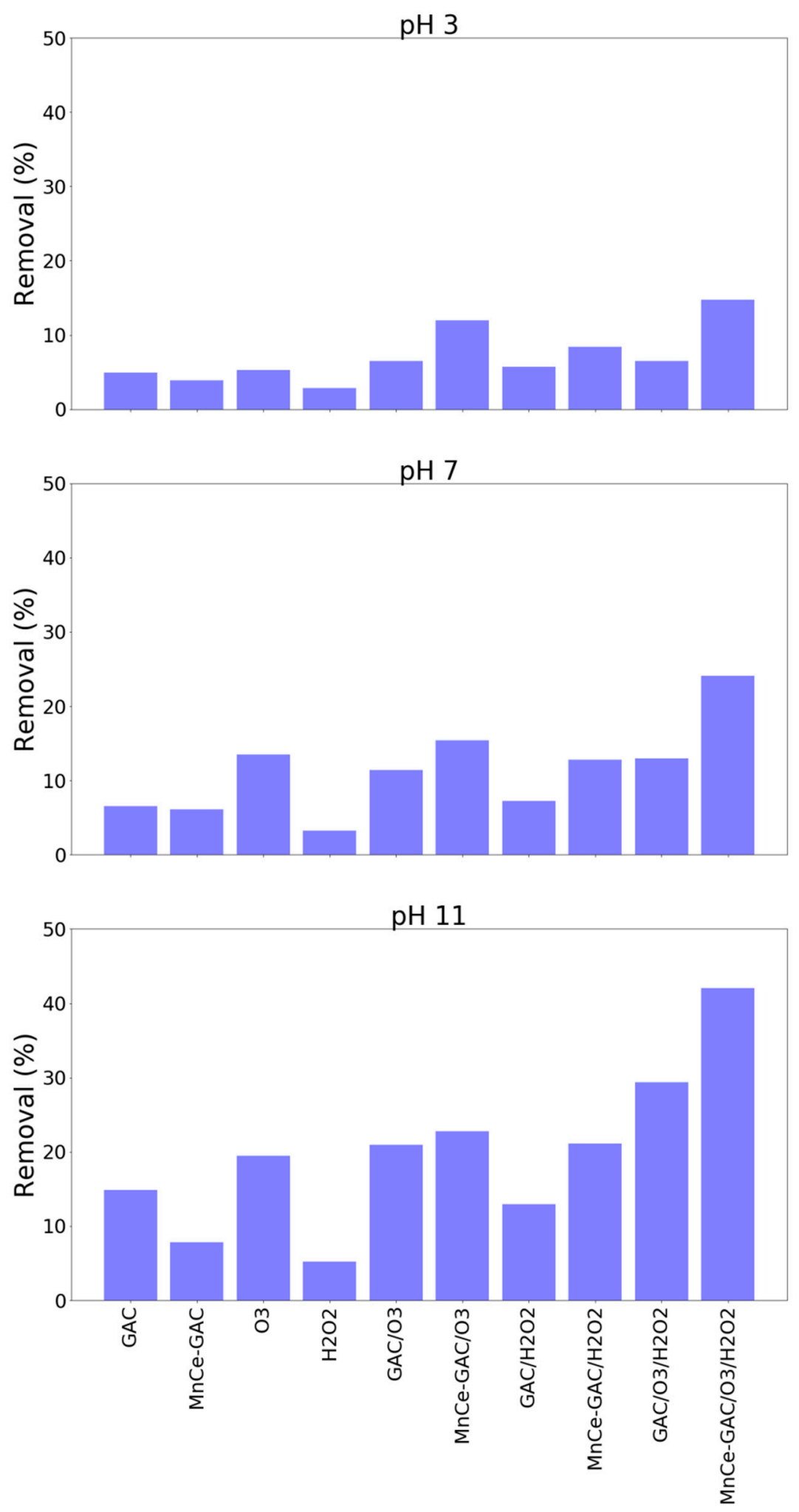

Figure 5. Removal of TMAH by various processes at various solution $\mathrm{pH}\left(\mathrm{C}_{\mathrm{o}}=100 \mathrm{mg} / \mathrm{L}, \mathrm{V}=0.5 \mathrm{~L}\right.$, solid $1 \mathrm{~g}$, $0.25 \mathrm{mmol} \mathrm{O}_{3} / \mathrm{min}, 0.125 \mathrm{mmol} \mathrm{H}_{2} \mathrm{O}_{2} / \mathrm{min}, 30 \mathrm{~min}$ ).

Since significant amounts of salts might be present in the wastewater, the effect of these salts on the processes has to be investigated in order to be able to apply the processes effectively in practice. Three types of salts such as sulfates, nitrates, and carbonates were chosen in this study as model compounds. As shown in Figure 6, these salts had a negative effect (Figure 6) on the removal of these 
pollutants at the tested $\mathrm{pH}$ values $(3,7$, and 11$)$. For example, ammonium removal decreased from 61 to 33,45 , and $36 \%$ due to the presence of sulfates $(100 \mathrm{mg} / \mathrm{L})$, nitrates $(500 \mathrm{mg} / \mathrm{L})$, and carbonates (500 mg/L) in solution, respectively (Figure 6). TMAH removal decreased from 80 to 46,41 , and $46 \%$ in aqueous solutions containing sulfates $(100 \mathrm{mg} / \mathrm{L})$, nitrates $(250 \mathrm{mg} / \mathrm{L})$, and carbonates $(250 \mathrm{mg} / \mathrm{L})$, respectively (Figure 7). Salts can affect the ozone oxidation process in several ways. For example, the presence of a salt generally lowers the solubility of a gas (salting out). A change in ozone solubility can be observed in the salt-containing solutions [28,29]. Rischbieter et al. [28] reported that sulfates and nitrates could reduce the solubility of ozone significantly with Henry constants about 15.3 and $12.1 \mathrm{kPa} \mathrm{m}^{3} \mathrm{~mol}^{-1}$, respectively (salt concentration $0.5 \mathrm{kmol} \mathrm{m}^{-3}$ ). Salts can also influence the size distribution of gas bubbles in a bubble column. They might inhibit bubble coalescence, resulting in a lower average bubble diameter. As a result, mass transfer rates might increase [30,31]. Carbonate ions are well-known species for scavenging the radicals involved in ozone decomposition [28,29,32]. On the other hand, sulfate, phosphate, nitrate, and chloride ions are extremely slow in reacting with $\bullet \mathrm{OH}$. Their scavenging effect can generally be neglected [33]. Therefore, the negative effect of sulfates and nitrates on pollutants removal might due to the salting-out effect.
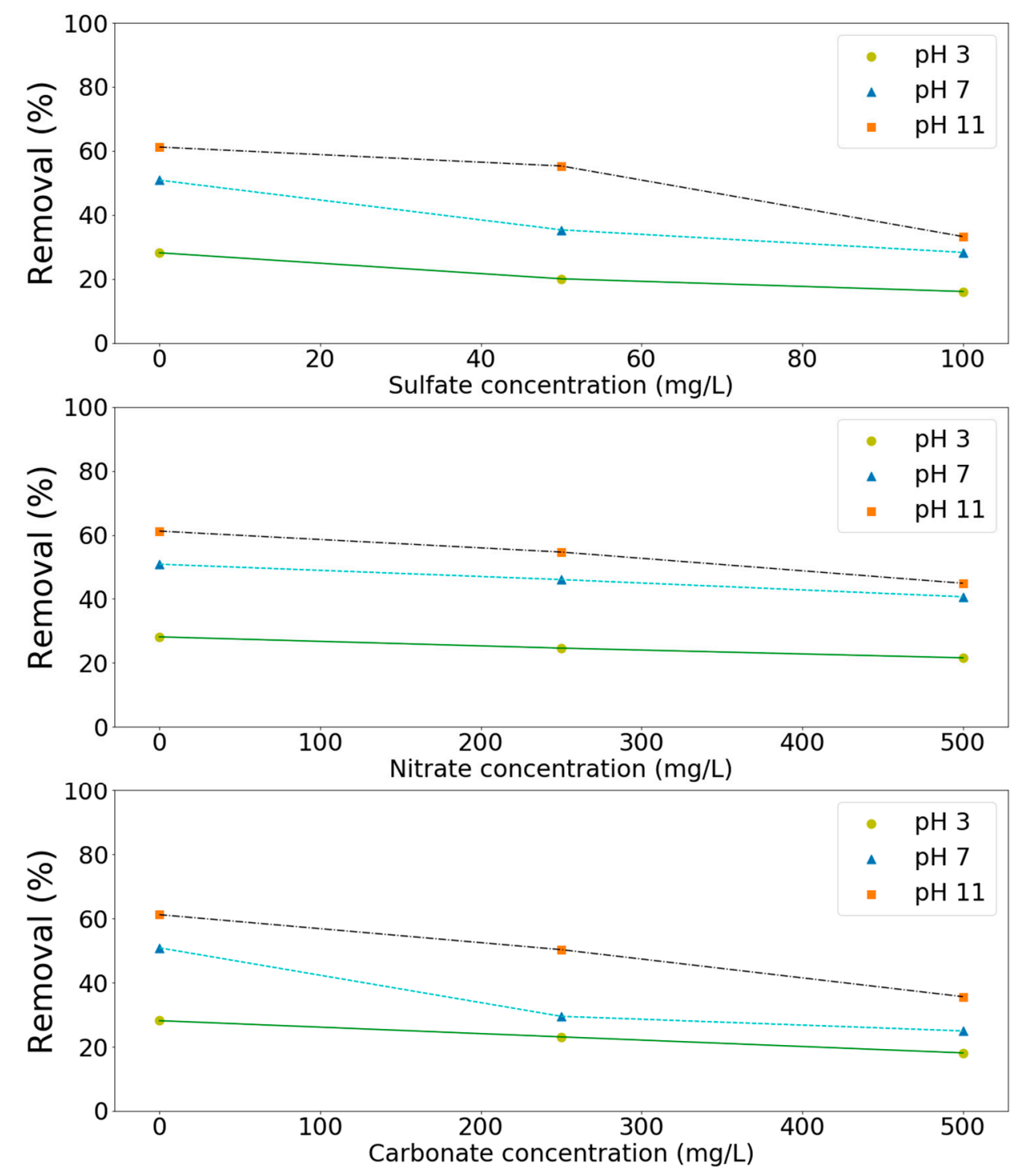

Figure 6. Effect of salts on the removal of ammonium by the MnCe-GAC/ $\mathrm{H}_{2} \mathrm{O}_{2}$ process $\left(\mathrm{C}_{\mathrm{o}}=100 \mathrm{mg} / \mathrm{L}\right.$, $\mathrm{V}=0.5 \mathrm{~L}$, solid $1 \mathrm{~g}, 0.25 \mathrm{mmol} \mathrm{O}_{3} / \mathrm{min}, 0.125 \mathrm{mmol} \mathrm{H}_{2} \mathrm{O}_{2} / \mathrm{min}, 30 \mathrm{~min}$ ). 

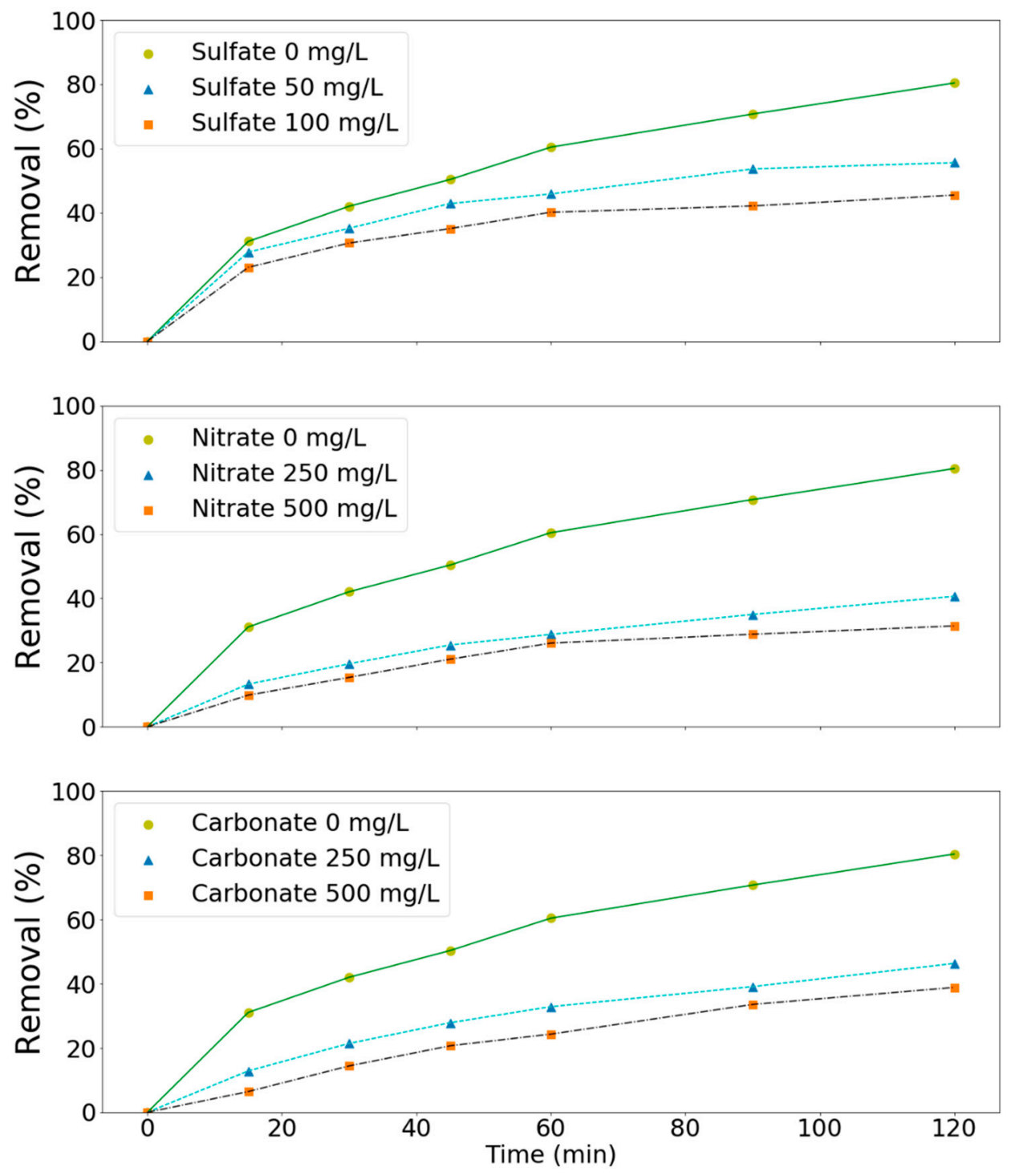

Figure 7. Effect of salts on the removal of TMAH by the MnCe-GAC/O $\mathrm{O}_{3} / \mathrm{H}_{2} \mathrm{O}_{2}$ process $\left(\mathrm{C}_{\mathrm{o}}=100 \mathrm{mg} / \mathrm{L}\right.$, $\mathrm{V}=0.5 \mathrm{~L}$, solid $1 \mathrm{~g}, 0.25 \mathrm{mmol} \mathrm{O}_{3} / \mathrm{min}, 0.125 \mathrm{mmol} \mathrm{H}_{2} \mathrm{O}_{2} / \mathrm{min}, 30 \mathrm{~min}$ ).

This study proposed that MnCe-GAC could enhance the formation of free radicals (such as hydroxyl radicals) in the MnCe- $\mathrm{GAC} / \mathrm{O}_{3} / \mathrm{H}_{2} \mathrm{O}_{2}$ process and subsequent oxidation of adsorbed pollutants [34,35]. This assumption was tested by the addition of t-butanol. t-Butanol has a high rate constant with $\bullet \mathrm{OH}$ as shown in Equation (1) [36].

$$
\mathrm{CH}_{3} \mathrm{C}\left(\mathrm{CH}_{3}\right)_{2} \mathrm{OH}+\bullet \mathrm{OH} \rightarrow \mathrm{CH}_{2} \mathrm{C}\left(\mathrm{CH}_{3}\right)_{2} \mathrm{OH}+\mathrm{H}_{2} \mathrm{O}\left(\mathrm{k}=6.0^{*} 10^{8} \mathrm{M}^{-1} \mathrm{~s}^{-1}\right)
$$

$\mathrm{t}$-Butanol could be used as a hydroxyl radical scavenger [37] and served as an $\bullet \mathrm{OH}$-scavenger in this study. If the removal of pollutants were significantly hindered by the addition of $t$-butanol, it indicated that the hydroxyl radical reaction might play an important role in the removal processes. The effect of $t$-butanol on the removal of ammonium and TMAH by the MnCe-GAC/O $/ \mathrm{O}_{3} / \mathrm{H}_{2} \mathrm{O}_{2}$ process is shown in Figure 8a,b, respectively. As indicated in the figure, the removal of ammonium as well as TMAH was significantly reduced due to the presence of t-butanol. For examples, the removal of ammonium decreased from 92 to $46 \%$ and the removal of TMAH decreased from 80 to $51 \%$. The removal efficiencies of ammonium and TMAH were reduced to 46 and $29 \%$, respectively, due to the presence of t-butanol. In agreement with the findings of Wang et al. [38], this result indicated 
that the hydroxyl radical reaction might play an important role in the removal processes. Kim and Choi [39] reported that $\bullet \mathrm{OH}$ could initiate the degradation of TMAH by either abstracting $\mathrm{H}$-atoms or adding hydrocarbon molecules. Chen et al. [40] reported that metal oxide catalysts (such as Mn-Ce-O composites) were efficient catalysts and they possessed many oxidation states to facilitate electron transfer processes in the radical-producing step of wet oxidation.

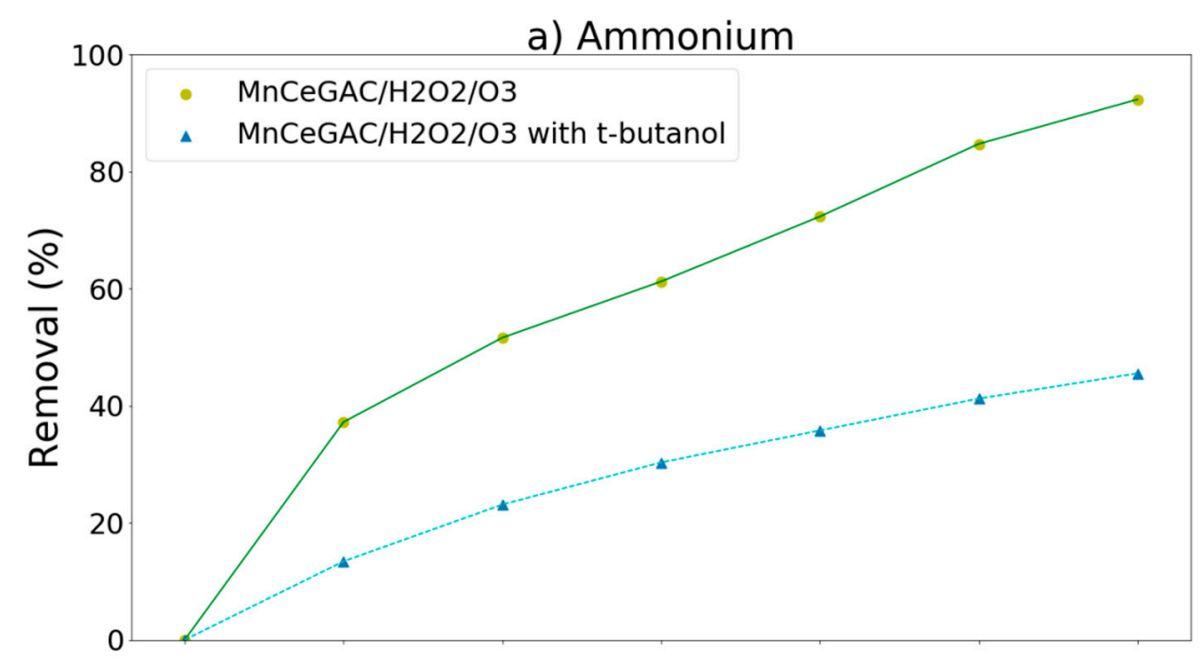

b) TMAH

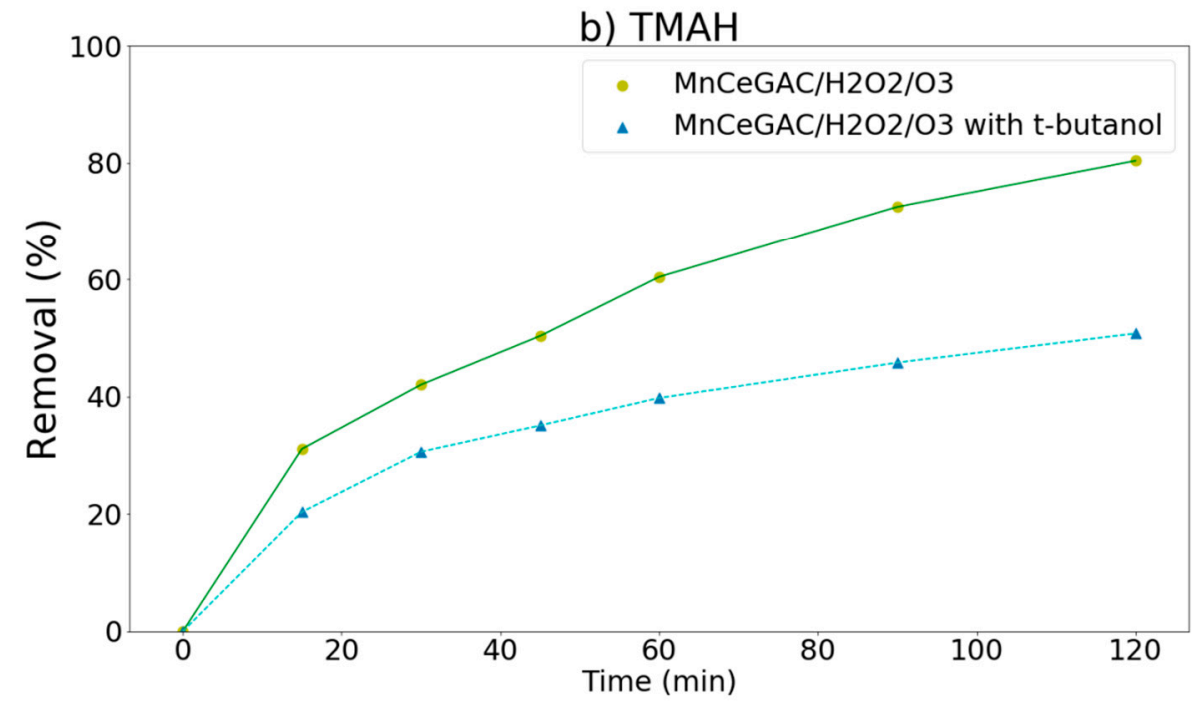

Figure 8. Effect of $t$-butanol on the removal of ammonium and TMAH by the MnCe- $\mathrm{GAC} / \mathrm{O}_{3} / \mathrm{H}_{2} \mathrm{O}_{2}$ process $\left(\mathrm{C}_{\mathrm{o}}=100 \mathrm{mg} / \mathrm{L}, \mathrm{V}=0.5 \mathrm{~L}\right.$, solid $\left.1 \mathrm{~g}, 0.25 \mathrm{mmol} \mathrm{O}_{3} / \mathrm{min}, 0.125 \mathrm{mmol} \mathrm{H}_{2} \mathrm{O}_{2} / \mathrm{min}\right)$.

\subsection{Real Wastewater}

The intermediate products produced during TMAH degradation [12] by the MnCe- $G A C / \mathrm{O}_{3} / \mathrm{H}_{2} \mathrm{O}_{2}$ process, including $\mathrm{NH}_{4}{ }^{+}, \mathrm{MH}, \mathrm{DH}$, and $\mathrm{TH}$ are presented in Figure 9. More than 80 and $73 \%$ of TMAH were removed in synthetic and real wastewaters, respectively. For example, in real wastewater, the concentrations of $\mathrm{NH}_{4}{ }^{+}, \mathrm{MH}, \mathrm{DH}, \mathrm{TH}$, and TMAH were under detection limit (ND), 3.38, 1.17, ND, and $26.89 \mathrm{mg} / \mathrm{L}$, respectively (120 min). Both $\mathrm{NH}_{4}{ }^{+}$and $\mathrm{TH}$ were not observed in the aqueous solution. A small amount of $\mathrm{MH}$ and $\mathrm{DH}$ (less than $3.5 \mathrm{mg} / \mathrm{L}$ ) was observed in the process. This result indicated that the MnCe-GAC/O $/ \mathrm{O}_{2} \mathrm{O}_{2}$ process could remove TMAH efficiently to meet the discharge limit of the Science Park $(30 \mathrm{mg} / \mathrm{L})$ for both synthetic and real wastewaters. 

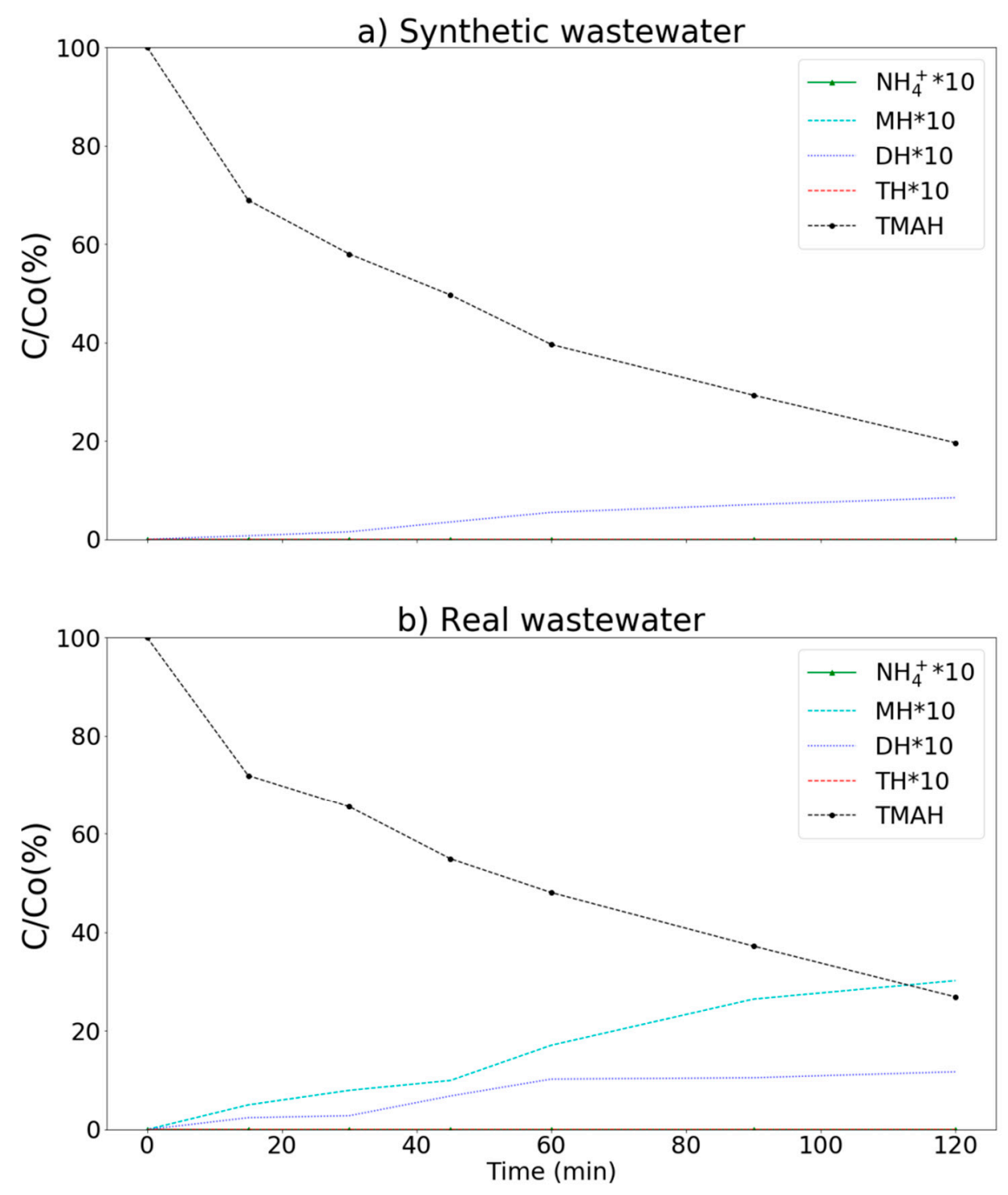

Figure 9. Degradation of TMAH by the MnCe-GAC/O $\mathrm{O}_{3} / \mathrm{H}_{2} \mathrm{O}_{2}$ process. (a) synthetic $(\mathrm{Co}=100 \mathrm{mg} / \mathrm{L}$ ) and $(\mathbf{b})$ real wastewater samples $\left(\mathrm{C}_{\mathrm{o}}=100 \mathrm{mg} / \mathrm{L}, \mathrm{V}=0.5 \mathrm{~L}\right.$, solid $1 \mathrm{~g}, 0.25 \mathrm{mmol} \mathrm{O} / \mathrm{min}, 0.125 \mathrm{mmol}$ $\left.\mathrm{H}_{2} \mathrm{O}_{2} / \mathrm{min}\right)$.

\subsection{Reaction Kinetics}

Experimental results indicated that the MnCe-GAC processes could effectively remove ammonium, MEA, and TMAH from aqueous solutions. In general, the removal of ammonium and MEA by these processes were better than that of TMAH as shown in Figure 10. Since the MnCe-GAC/O $/ \mathrm{O}_{2} \mathrm{O}_{2}$ process had the highest removal efficiency among these processes, reaction kinetics of the process was investigated. A suitable model could help in future design and implementation of the process. Many sophisticated models such as pore diffusion, homogeneous surface diffusion, and heterogeneous diffusion models have been developed to describe various kinetics processes. However, these models might not be convenient for practical use due to the mathematical complexity of these models [41,42]. Therefore, four simplified models (pseudo-first-order equation or generalized first order equation [41-43], pseudo-second-order equation [2], intra-particle diffusion model [2,38,43-46], and liquid film diffusion [46]) were applied in this research. 


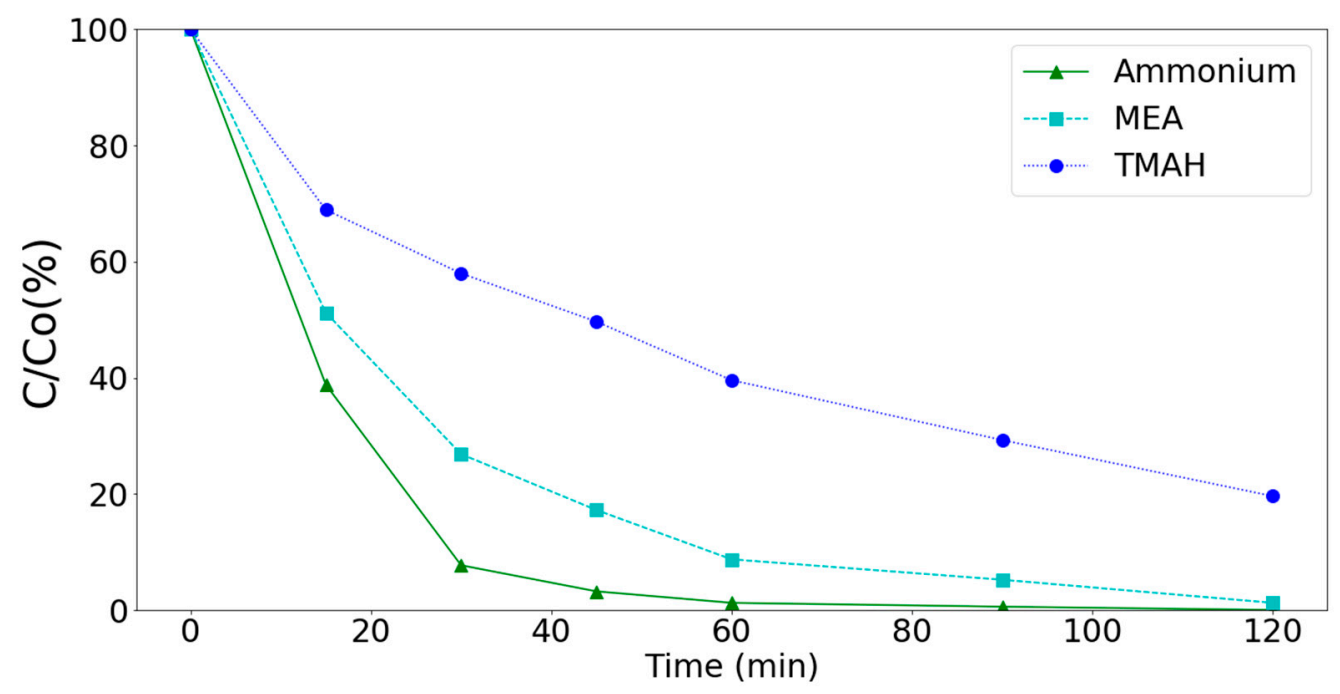

Figure 10. Degradation of ammonium, MEA, and TMAH by the MnCe-GAC/O $\mathrm{O}_{3} / \mathrm{H}_{2} \mathrm{O}_{2}$ process $\left(\mathrm{C}_{\mathrm{o}}=100 \mathrm{mg} / \mathrm{L}, \mathrm{V}=0.5 \mathrm{~L}\right.$, solid $\left.1 \mathrm{~g}, 0.25 \mathrm{mmol} \mathrm{O}_{3} / \mathrm{min}, 0.125 \mathrm{mmol} \mathrm{H}_{2} \mathrm{O}_{2} / \mathrm{min}\right)$.

Pseudo-first-order equation:

$$
\begin{gathered}
\frac{d q_{t}}{d t}=K_{1}\left(q_{e}-q_{t}\right), \\
\frac{1}{q_{t}}=\left(\frac{K_{1}}{q_{e}}\right)\left(\frac{1}{t}\right)+\frac{1}{q_{e}} .
\end{gathered}
$$

In the above equations, $q_{t}$ is the amount of adsorbate adsorbed $\left(\mathrm{mg} \mathrm{g}^{-1}\right)$ at time $t(\mathrm{~min}), q_{e}$ is the maximum adsorption capacity $\left(\mathrm{mg} \mathrm{g}^{-1}\right)$, and $K_{1}$ is the pseudo-first-order rate constant $\left(\mathrm{min}^{-1}\right)$ for the process.

Pseudo-second-order equation:

$$
\begin{aligned}
\frac{d q_{t}}{d t} & =K_{2}\left(q_{e}-q_{t}\right)^{2}, \\
\frac{t}{q_{t}} & =\frac{1}{K_{1} q_{e}^{2}}+\frac{t}{q_{e}} .
\end{aligned}
$$

In the above equations, $K_{2}$ is the pseudo-second-order rate constant $\left(\mathrm{g} \mathrm{mg}^{-1} \mathrm{~min}^{-1}\right)$.

Intra-particle diffusion model (or Weber and Morris' method):

$$
q_{t}=K_{p} \times t^{1 / 2}+C_{p}
$$

In the above equation, $C_{p}$ is the intercept $\left(\mathrm{mg} \mathrm{g}^{-1}\right)$ and $K_{p}$ is the intra-particle diffusion rate constant (mg $\min ^{-0.5} \mathrm{~g}^{-1}$ ).

Liquid film diffusion model:

$$
\ln \left(1-\frac{q_{t}}{q_{e}}\right)=-K_{L} t .
$$

In the above equation, $K_{L}$ is the liquid film diffusion rate constant $\left(\mathrm{min}^{-1}\right)$ for the adsorption process.

Experimental and simulation results are presented in Figure 11 and Table 2. To evaluate these models, root mean square error (RMSE) was calculated as follows:

$$
\text { RMSE }=\sqrt{\frac{\sum\left(q_{\text {exp }}-q_{p r e}\right)^{2}}{N}} .
$$




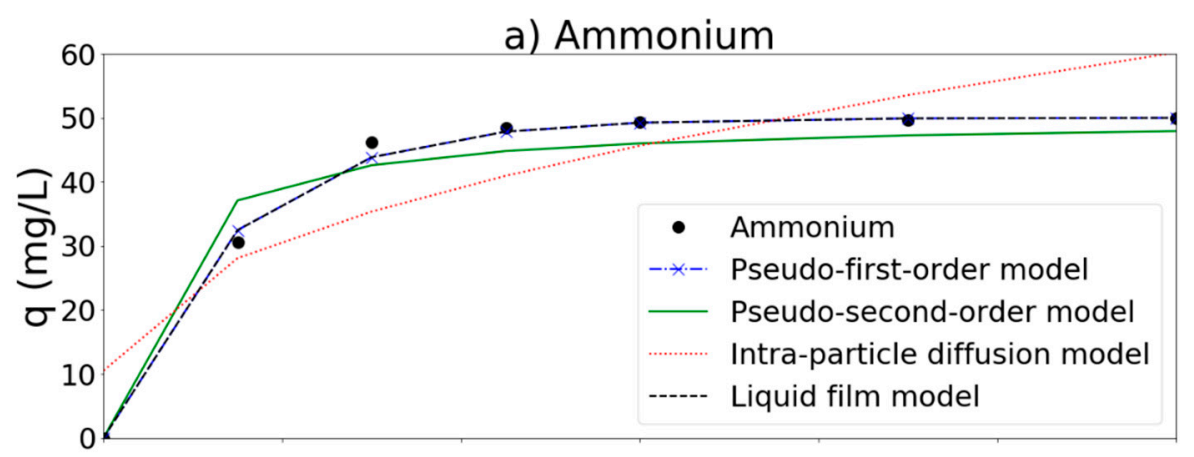

b) MEA

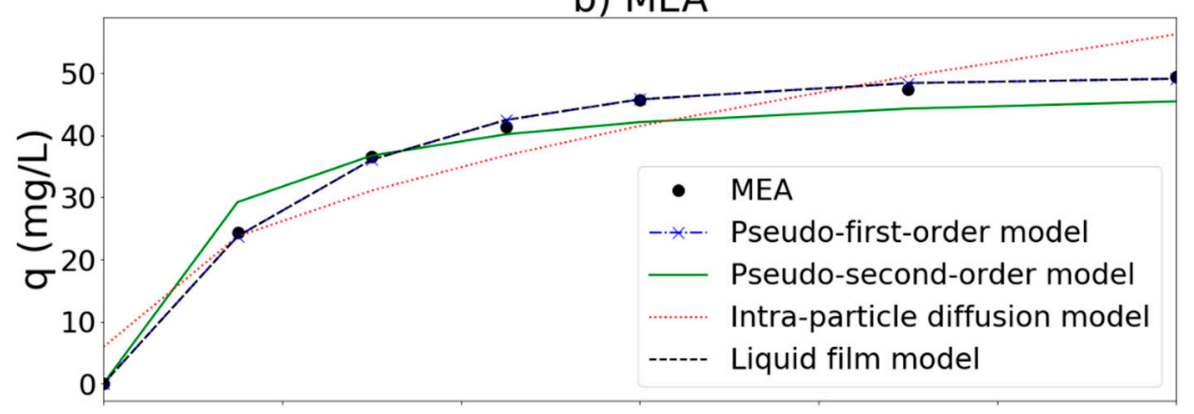

c) $\mathrm{TMAH}$

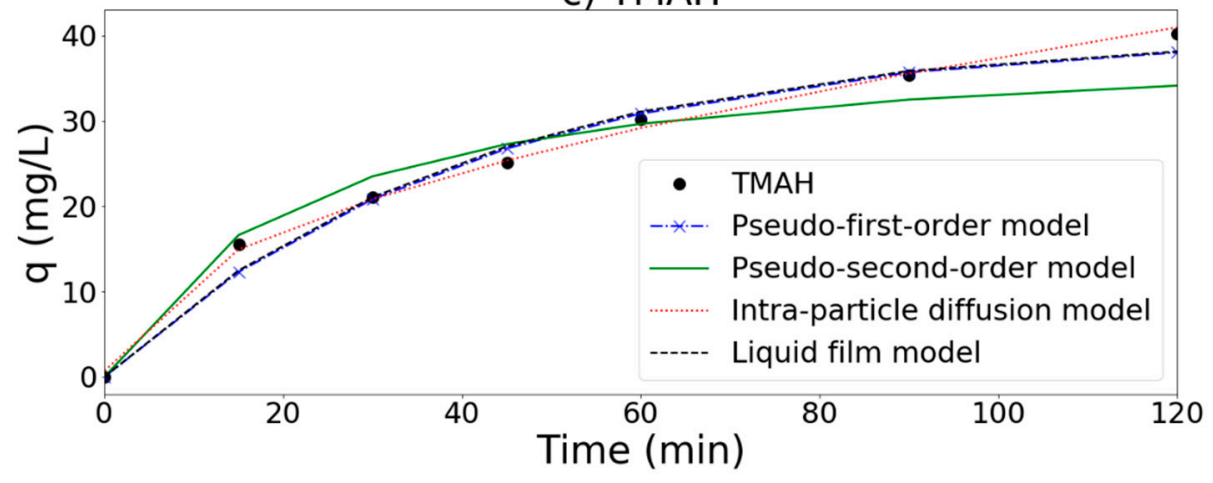

Figure 11. Removal of (a) ammonium, (b) MEA, and (c) TMAH by the MnCe-GAC/O $3 / \mathrm{H}_{2} \mathrm{O}_{2}$ process, respectively $\left(\mathrm{C}_{\mathrm{o}}=100 \mathrm{mg} / \mathrm{L}, \mathrm{V}=0.5 \mathrm{~L}\right.$, solid $\left.1 \mathrm{~g}, 0.25 \mathrm{mmol} \mathrm{O}_{3} / \mathrm{min}, 0.125 \mathrm{mmol} \mathrm{H}_{2} \mathrm{O}_{2} / \mathrm{min}\right)$.

Table 2. Simulation results with various kinetic models.

\begin{tabular}{ccccc}
\hline \multirow{2}{*}{ Models } & & \multicolumn{3}{c}{ Adsorbate } \\
\cline { 3 - 5 } & & Ammonium & MEA & TMAH \\
\hline Pseudo-first-order model & $\mathrm{K}_{1}$ & 0.161 & 0.101 & 0.056 \\
& $\mathrm{RMSE}$ & 1.31 & 0.43 & 2.61 \\
\hline Pseudo-second-order model & $\mathrm{K}_{2}$ & 0.00383 & 0.00196 & 0.00117 \\
& $\mathrm{RMSE}$ & 12.81 & 8.89 & 8.15 \\
\hline Intra-particle diffusion model & $\mathrm{K}_{\mathrm{p}}$ & 4.54 & 4.60 & 3.68 \\
& $\mathrm{C}_{\mathrm{p}}$ & 10.51 & 5.91 & 0.70 \\
& $\mathrm{RMSE}$ & 60.25 & 22.28 & 0.38 \\
\hline Liquid film model & $\mathrm{K}_{\mathrm{L}}$ & 0.0698 & 0.0437 & 0.0247 \\
& $\mathrm{RMSE}$ & 1.31 & 0.43 & 2.58 \\
\hline
\end{tabular}

In the above equation, $q_{\exp }$ and $q_{\text {pre }}$ are model experimental and predicted values, respectively, and $N$ is the number of data points. 
In general, a model with a smaller RMSE value is a better fit model. According to RMSE results (Table 2), both pseudo-first-order equation and liquid film diffusion models seem to fit the removal process of ammonium and MEA well with smaller RMSE values (1.31 and 0.43 for ammonium and MEA, respectively). This result is similar to the findings reported by Wang et al. [38], who reported that liquid film diffusion was probably the rate limiting step in an $\mathrm{MnCe}-\mathrm{AC} / \mathrm{O}_{3}$ process for the removal of humic acid in solution. On the other hand, the intra-particle diffusion model can better describe the removal process of TMAH (with lower RMSE $=0.38$ ). The pseudo-second order model was unable to fit these systems as indicated by a larger RMSE value. Based on the above simulations, liquid film diffusion is probably the rate limiting step for the removal of ammonium and MEA. Both ammonium and MEA probably transported from the bulk of the solution into the solid phase through the liquid film. For the removal of TMAH, it seemed that intra-particle diffusion played an important role in the process. TMAH was first adsorbed onto the MnCe-GAC surface, and then oxidized via catalytic reactions. This result is similar to the results presented by Fan et al. (2006), who reported that the intra-particle diffusion model was the best fitted model for $\mathrm{GAC} / \mathrm{H}_{2} \mathrm{O}_{2}$ and $\mathrm{FeGAC} / \mathrm{H}_{2} \mathrm{O}_{2}$ processes for the removal of acid black 24 .

\section{Conclusions}

An MnCe-GAC process combining $\mathrm{O}_{3}$ and $\mathrm{H}_{2} \mathrm{O}_{2}$ was evaluated in this research for the removal of nitrogen-containing wastewater, typical of high-tech industries. Experimental results indicated that the MnCe-GAC/O $\mathrm{O}_{3} / \mathrm{H}_{2} \mathrm{O}_{2}$ process could effectively lower ammonium, MEA, and TMAH concentrations to the desired levels. The presence of salts (carbonates, nitrates, or sulfates) interfered with the removal of these pollutants. Model simulation results indicated that the rate limiting step for the removal of ammonium and MEA is liquid film diffusion. On the other hand, intra-particle diffusion is probably the rate limiting step for the removal of TMAH by the MnCe-GAC/O $/ \mathrm{O}_{2} \mathrm{O}_{2}$ process. The process proposed in this study could be an effective alternative method for the treatment of high-tech industrial wastewater.

Author Contributions: Conceptualization, H.-J.F. and D.T.C.; Funding acquisition, H.-J.F. and D.P.; Investigation, D.T.C., D.P., J.-J.Z. and H.-J.F.; Methodology, D.T.C., H.-J.F. and J.-J.Z.; Writing-review \& editing, D.T.C., D.P. and H.-J.F.

Funding: This work was supported by Ministry of Science and Technology, Taiwan, R.O.C. (Grant no. MOST 107-2637-E-241-005) and Korea Environment Industry \& Technology Institute (KEITI) through Advanced Water Management Research Program, funded by Korea Ministry of Environment (MOE) (Grant 83089).

Conflicts of Interest: The authors declare no conflict of interest.

\section{References}

1. Su, C.-C.; Chen, C.-M.; Anotai, J.; Lu, M.-C. Removal of monoethanolamine and phosphate from thin-film transistor liquid crystal display (tft-lcd) wastewater by the fluidized-bed fenton process. Chem. Eng. J. 2013, 222, 128-135. [CrossRef]

2. Ligaray, M.; Futalan, C.M.; de Luna, M.D.; Wan, M.-W. Removal of chemical oxygen demand from thin-film transistor liquid-crystal display wastewater using chitosan-coated bentonite: Isotherm, kinetics and optimization studies. J. Clean. Prod. 2018, 175, 145-154. [CrossRef]

3. Zubel, I.; Kramkowska, M.; Rola, K. Silicon anisotropic etching in tmah solutions containing alcohol and surfactant additives. Sens. Actuators A Phys. 2012, 178, 126-135. [CrossRef]

4. Sindhuri, V.; Son, D.-H.; Lee, D.-G.; Sakong, S.; Jeong, Y.-H.; Cho, I.-T.; Lee, J.-H.; Kim, Y.-T.; Cristoloveanu, S.; Bae, Y.; et al. 1/f noise characteristics of algan/gan finfets with and without tmah surface treatment. Microelectron. Eng. 2015, 147, 134-136. [CrossRef]

5. Kuan-Foo, C.; Show-Ying, Y.; Huey-Song, Y.; Pan, J.R. Anaerobic treatment of tetra-methyl ammonium hydroxide (tmah) containing wastewater. IEEE Trans. Semicond. Manuf. 2008, 21, 486-491. [CrossRef]

6. Shibata, J.; Murayama, N.; Matsumoto, S. Recovery of tetra-methyl ammonium hydroxide from waste solution by ion exchange resin. Resour. Process. 2006, 53, 199-203. [CrossRef] 
7. Hori, H.; Wachi, S.; Iwamura, K.; Sano, T. Visible light-induced decomposition of monoethanolamine in water using graphitic carbon nitride as a photocatalyst. J. Photochem. Photobiol. A Chem. 2018, 351, 162-169. [CrossRef]

8. Wu, C.L.; Su, S.B.; Chen, J.L.; Chang, C.P.; Guo, H.R. Tetramethylammonium ion causes respiratory failure related mortality in a rat model. Resuscitation 2012, 83, 119-124. [CrossRef]

9. Liu, B.; Yoshinaga, K.; Wu, J.-H.; Chen, W.-Y.; Terashima, M.; Goel, R.; Pangallo, D.; Yasui, H. Kinetic analysis of biological degradation for tetramethylammonium hydroxide (tmah) in the anaerobic activated sludge system at ambient temperature. Biochem. Eng. J. 2016, 114, 42-49. [CrossRef]

10. Lin, C.C.; Yang, C.C.; Ger, J.; Deng, J.F.; Hung, D.Z. Tetramethylammonium hydroxide poisoning. Clin. Toxicol. (Phila) 2010, 48, 213-217. [CrossRef]

11. Chen, S.Y.; Lu, L.A.; Lin, J.G. Biodegradation of tetramethylammonium hydroxide (tmah) in completely autotrophic nitrogen removal over nitrite (canon) process. Bioresour. Technol. 2016, 210, 88-93. [CrossRef] [PubMed]

12. Lei, C.N.; Whang, L.M.; Chen, P.C. Biological treatment of thin-film transistor liquid crystal display (tft-lcd) wastewater using aerobic and anoxic/oxic sequencing batch reactors. Chemosphere 2010, 81, 57-64. [CrossRef] [PubMed]

13. Prahas, D.; Liu, J.C.; Ismadji, S.; Wang, M.-J. Adsorption of tetramethylammonium hydroxide on activated carbon. J. Environ. Eng. 2012, 138, 232-238. [CrossRef]

14. Chang, S.; Lin, K.-Y.A.; Lu, C. Efficient adsorptive removal of tetramethylammonium hydroxide (tmah) from water using graphene oxide. Sep. Purif. Technol. 2014, 133, 99-107. [CrossRef]

15. Chang, S.; Lu, C.; Lin, K.-Y.A. Comparisons of kinetics, thermodynamics and regeneration of tetramethylammonium hydroxide adsorption in aqueous solution with graphene oxide, zeolite and activated carbon. Appl. Surf. Sci. 2015, 326, 187-194. [CrossRef]

16. Chiou, C.-S.; Chuang, K.-J.; Lin, Y.-F.; Chen, H.-W.; Ma, C.-M. Application of ozone related processes to mineralize tetramethyl ammonium hydroxide in aqueous solution. Int. J. Photoenergy 2013, 2013, 191742. [CrossRef]

17. Hirano, K.; Okamura, J.; Taira, T.; Sano, K.; Toyoda, A.; Ikeda, M. An efficient treatment technique for tmah wastewater by catalytic oxidation. IEEE Trans. Semicond. Manuf. 2001, 14, 202-206. [CrossRef]

18. Wang, Y.; Zhang, Z.; Jiang, C.; Xu, T. Electrodialysis process for the recycling and concentrating of tetramethylammonium hydroxide (tmah) from photoresist developer wastewater. Ind. Eng. Chem. Res. 2013, 52, 18356-18361. [CrossRef]

19. Wang, C.-W.; Liang, C. Oxidative degradation of tmah solution with uv persulfate activation. Chem. Eng. J. 2014, 254, 472-478. [CrossRef]

20. Huang, J.; Wang, K.S.; Liang, C. Oxidative degradation of tetramethylammonium hydroxide (tmah) by uv/persulfate and associated acute toxicity assessment. J. Environ. Sci. Health Part A 2017, 52, 930-937. [CrossRef]

21. Federation, W.E.; American Public Health Association. Standard Methods for the Examination of Water and Wastewater; American Public Health Association: Washington, DC, USA, 2005.

22. Kishimoto, N.; Nakamura, E. Bromate formation characteristics of uv irradiation, hydrogen peroxide addition, ozonation, and their combination processes. Int. J. Photoenergy 2012, 2012, 107293. [CrossRef]

23. Afzal, A.; Chelme-Ayala, P.; Drzewicz, P.; Martin, J.W.; Gamal El-Din, M. Effects of ozone and ozone/hydrogen peroxide on the degradation of model and real oil-sands-process-affected-water naphthenic acids. Ozone Sci. Eng. 2015, 37, 45-54. [CrossRef]

24. Hey, G.; Vega, S.R.; Fick, J.; Tysklind, M.; Ledin, A.; La Cour Jansen, J.; Andersen, H.R. Removal of pharmaceuticals in wwtp effluents by ozone and hydrogen peroxide. Water SA 2014, 40, 165-174. [CrossRef]

25. Gottschalk, C.; Libra, J.; Saupe, A. Ozonation of Water and Waste Water: A Practical Guide to Understanding Ozone and its Application; John Wiley \& Sons: Hoboken, NJ, USA, 2000; p. 189.

26. Lu, L.-W.; Peng, Y.-P.; Chang, C.-N. Applying an activated carbon/silver catalyst to the decomposition of the aqueous solutions of tetramethyl ammonium hydroxide. J. Taiwan Inst. Chem. Eng. 2018, 88, 130-136. [CrossRef]

27. Tong, S.-P.; Xie, D.-M.; Wei, H.; Liu, W.-P. Degradation of sulfosalicylic acid by o3/uv o3/tio2/uv, and o3/v-o/tio2: A comparative study. Ozone Sci. Eng. 2005, 27, 233-238. [CrossRef] 
28. Rischbieter, E.; Stein, H.; Schumpe, A. Ozone solubilities in water and aqueous salt solutions. J. Chem. Eng. Data 2000, 45, 338-340. [CrossRef]

29. Sotelo, J.L.; Beltrán, F.J.; González, M.; Domínguez, J. Effect of high salt concentrations on ozone decomposition in water. J. Environ. Sci. Health Part A 2008, 24, 823-842. [CrossRef]

30. Christenson, H.K.; Yaminsky, V.V. Solute effects on bubble coalescence. J. Phys. Chem. 1995, 99, 10420. [CrossRef]

31. Walker, A.B.; Tsouris, C.; DePaoli, D.W.; Thomas Klasson, K. Ozonation of soluble organics in aqueous solutions using microbubbles. Ozone Sci. Eng. 2001, 23, 77-87. [CrossRef]

32. Boncz, M.A.; Bruning, H.; Rulkens, W.H.; Zuilhof, H.; Sudhölter, E.J.R. The effect of salts on ozone oxidation processes. Ozone Sci. Eng. 2005, 27, 287-292. [CrossRef]

33. Hoigné, J. Chemistry of aqueous ozone and transformation of pollutants by ozonation and advanced oxidation processes. In Quality and Treatment of Drinking Water II; Hrubec, J., Ed.; Springer: Berlin, Germany, 1998; pp. 83-141.

34. Tizaoui, C.; Bouselmi, L.; Mansouri, L.; Ghrabi, A. Landfill leachate treatment with ozone and ozone/hydrogen peroxide systems. J. Hazard. Mater. 2007, 140, 316-324. [CrossRef] [PubMed]

35. Peixoto, A.L.C.; Silva, M.B.; Izário Filho, H.J. Leachate treatment process at a municipal stabilized landfill by catalytic ozonation: An exploratory study from taguchi orthogonal array. Braz. J. Chem. Eng. 2009, 26, 481-492. [CrossRef]

36. Buxton, G.V.; Greenstock, C.L.; Helman, W.P.; Ross, A.B. Critical review of rate constants for reactions of hydrated electrons, hydrogen atoms and hydroxyl radicals in aqueous solution. J. Phys. Chem. Ref. Data 1988, 17, 513-886. [CrossRef]

37. Ismail, M.; Khan, H.M.; Sayed, M.; Cooper, W.J. Advanced oxidation for the treatment of chlorpyrifos in aqueous solution. Chemosphere 2013, 93, 645-651. [CrossRef] [PubMed]

38. Wang, J.-M.; Lu, C.-S.; Chen, Y.-Y.; Chang, D.T.; Fan, H.-J. Landfill leachate treatment with mn and ce oxides impregnated gac-ozone treatment process. Colloids Surf. A Physicochem. Eng. Asp. 2015, 482, 536-543. [CrossRef]

39. Kim, S.; Choi, W. Kinetics and mechanisms of photocatalytic degradation of (ch3)nnh4-n+ $(0 \leq n \leq 4)$ in tio2 suspension: The role of oh radicals. Environ. Sci. Technol. 2002, 36, 2019-2025. [CrossRef]

40. Chen, H.; Sayari, A.; Adnot, A.; Larachi, F. Composition-activity effects of mn-ce-o composites on phenol catalytic wet oxidation. Appl. Catal. B Environ. 2001, 32, 195-204. [CrossRef]

41. Crank, J. The Mathematics of Diffusion; Oxford University Press: Oxford, UK, 1979.

42. Wilczak, A.; Keinath, T.M. Kinetics of sorption and desorption of copper (ii) and lead (ii) on activated carbon. Water Environ. Res. 1993, 65, 238-244. [CrossRef]

43. Fan, H.J.; Shu, H.Y.; Tajima, K. Decolorization of acid black 24 by the fegac/h2o2 process. J. Hazard. Mater. 2006, 128, 192-200. [CrossRef]

44. Kannan, N.; Sundaram, M.M. Kinetics and mechanism of removal of methylene blue by adsorption on various carbons-A comparative study. Dye. Pigment. 2001, 51, 25-40. [CrossRef]

45. Onundi, Y.B.; Mamun, A.A.; Al khatib, M.; Ahmed, Y.M. Adsorption of copper, nickel and lead ions from synthetic semiconductor industrial wastewater by palm shell activated carbon. Int. J. Environ. Sci. Technol. 2010, 7, 751-758. [CrossRef]

46. Al-Khateeb, L.A.; Almotiry, S.; Salam, M.A. Adsorption of pharmaceutical pollutants onto graphene nanoplatelets. Chem. Eng. J. 2014, 248, 191-199. [CrossRef]

(C) 2019 by the authors. Licensee MDPI, Basel, Switzerland. This article is an open access article distributed under the terms and conditions of the Creative Commons Attribution (CC BY) license (http://creativecommons.org/licenses/by/4.0/). 